Hydrothermal Processes and Mineral Systems 


\section{Hydrothermal Processes and Mineral Systems}

Franco Pirajno

Geological Survey of Western Australia, Perth, WA, Australia

Foreword by Peter A. Cawood

Springer Geological Survey of Western Australia 


\section{Franco Pirajno}

Geological Survey of Western Australia

100 Plain St.

East Perth WA 6004

Australia

franco.pirajno@dmp.wa.gov.au

First published 2009

Reprinted with corrections 2010

ISBN: 978-1-4020-8612-0

e-ISBN: 978-1-4020-8613-7

Library of Congress Control Number: 2008933283

(C) Springer Science+Business Media B.V. 2009, 2010

No part of this work may be reproduced, stored in a retrieval system, or transmitted in any form or by any means, electronic, mechanical, photocopying, microfilming, recording or otherwise, without written permission from the Publisher, with the exception of any material supplied specifically for the purpose of being entered and executed on a computer system, for exclusive use by the purchaser of the work.

Cover illustration: Fig. 3.1 in this book. Figure designed and produced by Murray C. Jones.

Printed on acid-free paper

$\begin{array}{lllllllll}9 & 8 & 7 & 6 & 5 & 4 & 3 & 2 & 1\end{array}$

springer.com 
To my wife 


\section{Foreword}

The Earth is a complex and dynamic system that over 4.5 billion years has evolved to form the environment we live in and the resources we depend on. Franco Pirajno's book "Hydrothermal Processes and Mineral Systems" provides an authoritative and comprehensive overview of hyrdrothermally controlled major mineral resources that have developed in this dynamic system, and where appropriate their links with the development of life and extraterrestrial hydrothermal systems.

Discovery and recovery of mineral resources are fundamental to sustaining human society. Yet the discovery of world-class to giant mineral deposits has declined alarmingly over the last few decades. It is only through a comprehensive understanding of current systems that we can hope to find future deposits. This book provides an unparalleled overview of the principal features of the major mineral systems and the role of fluid circulation in their development, including: the variety of water sources that participate in hydrothermal circulation systems (Chapter 1), the alteration patterns associated with hydrothermal circulation in selected mineral systems (Chapter 2), the link with tectonic settings and interaction between the lithosphere, hydrosphere and biosphere (Chapter 3), the major mineral system types including intrusion-related (Chapter 4), porphyry and epithermal, skarn (Chapter 5), sedimentary exhalative (SEDEX) Mississippi valley-type (MVT)(Chapter 6), submarine (Chapters 7 and 8), amagmatic and other hydrothermal systems (Chapter 9) and uranium systems (Chapter 13). The book also looks the interrelationship between hydrothermal systems and life, detailing the ecosystems that develop (Chapter 10), the hydrothermal systems driven by the thermal energy from meteorite impacts (Chapter 11) and possible hydrothermal systems on other planets in the solar system (Chapter, 12). This is truly a comprehensive treatment of hydrothermal processes and mineral systems.

Franco Pirajno commenced his academic studies in his native Italy where he obtained a Doctorate in Geological Sciences from the Vesuvius Volcano Observatory of Federico II University in Naples. He has had a diverse career in industry, government and academia that included 19 years in mineral exploration with the Anglo-American Corporation of South Africa, the Chair of Economic Geology at Rhodes University, South Africa, and since 1993, the Geological Survey of Western Australia. He has held visiting professorships at 
Peking University and China University of Geosciences and currently has honorary appointments at the Astrobiology Centre, University of New South Wales, Sydney, and the China University of Geosciences, Beijing. Franco Pirajno is the author of two books, authored or co-authored a monograph and more than 100 peer-reviewed papers and 19 geological maps in Western Australia, Namibia and Greenland. Throughout his career, which has included work in Europe, southern Africa, South East Asia, New Zealand, the southwest Pacific, China, Greenland and Australia, he has integrated experience in tectonics, ore deposit geology and mineral exploration. It is this wealth of firsthand experience, including the little known mineral systems in China, which Franco Pirajno weaves with a distillation of relevant literature into his comprehensive overview of "Hydrothermal Processes and Mineral Systems".

The University of Western Australia, Perth

Peter A. Cawood May 2008 


\section{Acknowledgments}

I owe a debt of gratitude to several colleagues and friends. In no special order I thank Martin Van Kranendonk of the Geological Survey of Western Australia (GSWA) for stimulating discussions and for reviewing Chapter 10; other reviewers included Peter Cawood of the University of Western Australia (Chapter 5), Richard Langford (GSWA; Chapters 1 and 6), Doug Kirwin (Ivanhoe Mines; Chapter 4); Simon Johnson (GSWA; Chapter 13). Murray Jones, Arthur Hoffman, Michael Prause and Dellys Sutton (all with GSWA) drafted the figures; Murray and Arthur gave their time even when under pressure for other jobs. Nell Stoyanoff (GSWA) typed most of the tables, especially the complex ones. Jean Johnston and Chris Hocking performed the unenviable task of editing the references. Brian Knyn and Eunice Cheung (Department of Industry and Resources library) managed to meet with my never-ending appetite for books and papers, often at short notice. Tim Griffin, Executive Director of GSWA, supported the writing of this book, and on behalf of GSWA funded the cost of colour figures. I thank my Chinese friends and colleagues for their hospitality and support for the numerous field trips in China and their patience with the idiosyncrasies of a Westerner: Chen Yanjing (Peking University), Mao Jingwen (Institute of Mineral Resources, Chinese Academy of Geological Sciences, Beijing), Zhang Shihong and Han Higuy (China University of Geosciences, Beijing), Xiao Long (China University of Geosciences, Wuhan).

Once again, I dedicate this book to my wife and lifelong companion, unwavering in her support, even when faced with harsh conditions in the field, abroad and in outback Australia. 


\section{Contents}

1 Water and Hydrothermal Fluids on Earth $\ldots \ldots \ldots \ldots \ldots \ldots \ldots$. 1

1.1 Introduction .......................... 1

1.2 Origin of Water; Sea and Surface Waters . . . . . . . . . . 5

$1.2 .1 \quad$ Seawater. . . . . . . . . . . . . . . . . . 9

1.2 .2 Surface Water . . . . . . . . . . . . . . . 13

1.2 .3 Groundwater....................... 15

1.3 Structure and Properties of Water; Hydration and Hydrolysis. 17

1.4 Hydrothermal Fluids . . . . . . . . . . . . . . . . . . . 18

1.4.1 Solubility and Boiling .................. 22

1.4.2 Acid-Base Nomenclature. . . . . . . . . . . . . . . . . . 23

1.4.3 Redox Potential. ...................... 24

1.4.4 Chemical Potential, Chemical Activity, Fugacity, Oxygen Fugacity ......................... 26

1.4 .5 Hot Springs . . . . . . . . . . . . . . . . . 30

1.4.6 Fluid Inclusions...................... 38

1.4.7 Dissolved Constituents and Metals Partitioning in Hydrothermal Solutions ................. 42

1.4.8 The Role of Complex Ions and Ligands in Hydrothermal Fluids............................. 44

1.4.9 Complex Ions in Hydrothermal Solutions . . . . . . . . . 47

1.4.10 Precipitation of Solutes and Metal Deposition....... 50

1.4.11 Isotopic Tracers. . . . . . . . . . . . . . . . . . . . . . 51

1.5 Concluding Remarks . . . . . . . . . . . . . . . . . . . . 64

References............................... 65

2 Hydrothermal Processes and Wall Rock Alteration . . . . . . . . . . 73

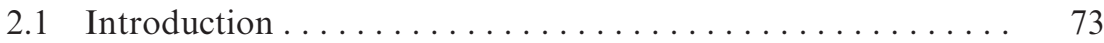

2.1.1 The Main Components of a Hydrothermal System . . . 74

2.1.2 Magma Degassing and Magmatic Hydrothermal Systems 80

2.2 Role of Volatiles in Granitic Magmas . . . . . . . . . . . . 86

2.3 Hydrothermal Alteration . . . . . . . . . . . . . . . . . . 90

2.3.1 Hydrogen Ion Metasomatism (Hydrolytic Alteration) and Base Cation Exchange ................. 91 
2.3.2 Styles and Types of Hydrothermal Alteration ........ 94

2.4 Intrusion-Related Alkali Metasomatism . . . . . . . . . . . . 104

2.4.1 Sodic Metasomatism and Albitites ............... 104

2.4.2 Potassic Metasomatism and Microclinites .......... 105

2.5 Alkali Metasomatism (Fenites) in Anorogenic Ring Complexes 106

$2.5 .1 \quad$ Fenites . . . . . . . . . . . . . . . . . . . 107

2.6 Alteration in Porphyry Systems . . . . . . . . . . . . . 111

2.6.1 Lowell-Guilbert and Breccia Pipe Models .......... 114

2.6.2 Diorite Model ......................... 117

2.6.3 Hydrothermal Alteration in Climax-Type Porphyry Mo Systems . . . . . . . . . . . . . . . . . . . . . . 117

$2.7 \quad$ Skarns.................................. 119

2.8 Alteration in Epithermal Systems . . . . . . . . . . . 120

2.8.1 Siliceous Precipitates, Self-Sealing and Hydrothermal Breccias ......................... 122

2.9 Hydrothermal Alteration in Submarine Mineral Systems .... . 124

2.9.1 Hydrothermal Alteration in Kuroko-Type Mineral Systems ............................ 125

2.9.2 Oceanic Crust Hydrothermal Metamorphism ...... 126

2.10 Other Types of Alteration . . . . . . . . . . . . . . . . . 131

2.10 .1 Tourmalinisation. ..................... 132

2.10.2 Serpentinisation and Talc-Carbonate Alteration ..... 133

2.10.3 Hematitisation and Fe-Rich Alteration .......... 135

2.10.4 Carbonatisation and Dolomitisation ............ 136

2.11 Metamorphism of Hydrothermally Altered Rock . . . . . . . 137

2.12 Geochemical Signatures and Isotopic Tracers . . . . . . . . . . 143

2.12 .1 Geochemistry. . . . . . . . . . . . . . . . . . . 143

2.12 .2 Isotopic Tracers. . . . . . . . . . . . . . . 151

2.13 Detection of Hydrothermal Alteration from Spectral Remote

Sensing ............................ 153

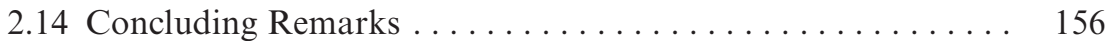

References............................ 157

\section{Tectonic Settings, Geodynamics and Temporal Evolution of}

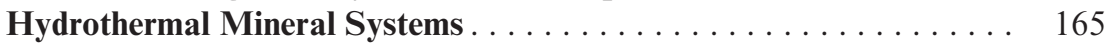

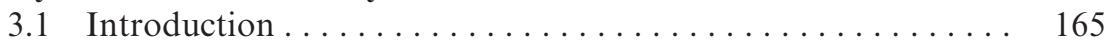

3.2 Tectonic Settings and Geodynamics of Mineral Systems..... 166

3.2.1 Convergent Plate Boundaries; Arc and Back-Arc

Settings, Collision Tectonics,.............. 171

3.2.2 Divergent Plate Boundaries; Mid-Oceanic Ridges,

Passive Margins and Continental Rifting .......... 178

3.2.3 Mantle Plumes Tectonics and Hydrothermal Systems . . 187

3.3 Metallogeny and Geodynamics ................. 188

3.4 Temporal Evolution of Ore Systems, Supercontinent Cycles and

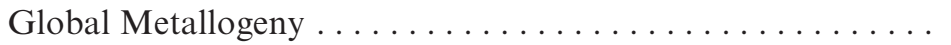


3.5 Concluding Remarks . . . . . . . . . . . . . . . . . . . . . . . . 199

References......................................... 199

4 Intrusion-Related Hydrothermal Mineral Systems. . . . . . . . . . . . 205

$4.1 \quad$ Introduction ........................ 205

4.2 Intrusion-Related Hydrothermal Mineral Systems and Granitic Magmatism............................. 207

4.3 Greisen Ore Systems. . . . . . . . . . . . . . . . . . . . . . . 218

4.3.1 Greisenisation Processes . . . . . . . . . . . . . 220

4.3.2 Geochemistry...................... 227

4.3.3 Greisen-Style Mineral Systems ................ 227

4.3.4 Sn and W Geochemistry in the Greisen System and Deposition of Cassiterite and Wolframite......... 228

4.3.5 Tin Deposits Associated with the Felsic Phase of the Bushveld Igneous Complex, South Africa ......... 230

4.3.6 The Sn-W Deposits of Southwest England, Cornwall and Portugal ...................... 238

4.3.7 The Greisen Systems of the Tasman Fold Belt System. . 244

4.3.8 The East Kemptville Sn Greisen, Nova Scotia, Canada . 248

4.3.9 The Brandberg West Greisen Vein Systems, Namibia . . 250

4.3.10 The Kalguta Mo-W-Be-Bi Greisen System, Southeastern Altai (Russia). . . . . . . . . . . . . . . . . . . . . . 258

4.4 Intrusion-Related Gold, Polymetallic and Uraniferous Vein Systems and Breccia Pipes . . . . . . . . . . . . . . . . 260

4.4.1 Scheelite Dome, an Intrusion-Related Au Deposit, Yukon, Canada ........................ 262

4.4.2 The Kidston Breccia Pipe, Queensland, Australia . . . . . 269

4.4.3 Uraniferous Vein Systems . . . . . . . . . . . . . . . . . 272

4.4.4 Sabie-Pilgrim's Rest, South Africa . . . . . . . . . . . . 273

4.4.5 Capricorn Orogen Structurally Controlled Hydrothermal Vein (Base and Precious Metals), Western Australia ......................... 275

4.4.6 Polymetallic Vein Systems of the Altai (Siberia) and Northwestern Mongolia (Yustid Rift Zone) . . . . . . . . 277

4.5 Hydrothermal Systems Associated with Alkaline Magmatism and Anorogenic Ring Complexes............... 280 4.5.1 Tectonic Settings, Ages and Controls of Intracontinental Alkaline Magmatism in Africa ................. 283

4.5.2 Ore Systems of Alkaline Ring Complexes.......... . 285

4.6 Iron Oxide-Copper-Gold-Rare Earth Elements-Uranium Mineral Systems . . . . . . . . . . . . . . . . . . . . . . 306

4.6.1 Olympic Dam, South Australia................. 312

4.6.2 Vergenoeg Fe Oxides-Fluorite Deposit, South Africa . . 322

4.6.3 The Palabora Complex (South Africa) ........... 326

4.6.4 Bayan Obo REE-Nb-Fe Deposit, Inner Mongolia, China 328 
4.6.5 Candelaria, Punta Del Cobre District, Chilean Coastal Belt. ....................... 336

4.7 Concluding Remarks . . . . . . . . . . . . . . . . . 339

References............................ 340

5 Porphyry Systems; Fossil and Active Epithermal Systems . . . . . . . . 355

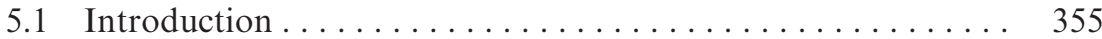

5.2 Porphyry Systems. . . . . . . . . . . . . . . . . . . 356

5.2.1 Porphyry Systems of Convergent Margins . . . . . . . . . 367

5.2.2 Porphyry Systems in Intracontinental Extensional Tectonic Settings and Volcanic Rifted Margins . . . . . . 390

5.2.3 The Oldest Porphyry Systems . . . . . . . . . . . . . . . . . 419

5.3 Fossil and Active Epithermal Systems . . . . . . . . . . . 422

5.3.1 Fossil Epithermal Systems. . . . . . . . . . . . . 426

5.3.2 Ladolam Epithermal System, Lihir Island, Papua New Guinea ........................ 442

5.3.3 Hauraki Goldfield, Coromandel Peninsula, New Zealand 448

5.3.4 The Epithermal Systems of the Biga Peninsula, Northwestern Anatolia . . . . . . . . . . . . . . . . 456

5.3.5 Epithermal Systems in the South China Fold Belt . . . . 463

5.3.6 The El Indio-Pascua Wpithermal Belt, Chile . . . . . . . 475

5.3.7 Epithermal Systems in the Northern Great Basin, USA. 481

5.3.8 The Oldest Epithermal Systems, Archaean Pilbara and Yilgarn Cratons, Western Australia ............ 486

5.4 Active Epithermal Systems (Geothermal Fields) . . . . . . . . . . . 493

5.4.1 Kamchatka Peninsula and Kurile Islands. . . . . . . . . . 497

5.4.2 Geothermal Systems of the Taupo Volcanic Zone, New Zealand ..................... 500

5.4.3 Geysers-Clear Lake Geothermal System, California, USA ....................... 505

5.4.4 The Yellowstone National Park Geothermal System, USA . . . . . . . . . . . . . . . . . . . . 507

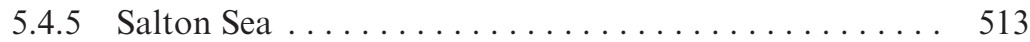

5.4 .6 Lake Tanganyika. . . . . . . . . . . . . . . . 515

5.5 Concluding Remarks .................... 516

References.......................... 517

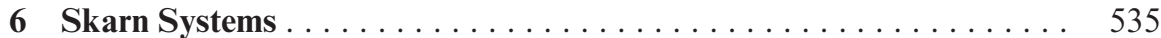

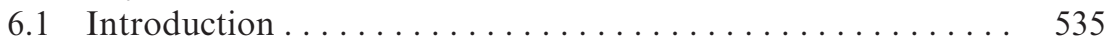

6.2 Copper Skarns . . . . . . . . . . . . . . . . . . . . 546

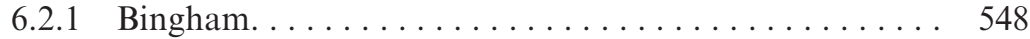

6.2 .2 Yerington. . . . . . . . . . . . . . . . . . . . . 549

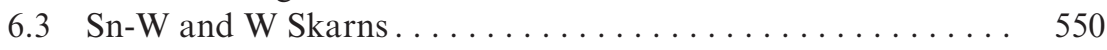

6.3 .1 Moina $\mathrm{Sn}-\mathrm{W}$ Deposit. . . . . . . . . . . . . . . 551

6.3.2 King Island Scheelite Deposit . . . . . . . . . . . . . 552 
6.4 Proterozoic W Skarns in the Gascoyne Complex, Western Australia............................... 553

6.5 Gold Skarns . . . . . . . . . . . . . . . . . . . 558

6.5 .1 Navachab, Namibia. . . . . . . . . . . . . . . . . . . 560

6.5.2 Gold Skarns in China . . . . . . . . . . . . . . . . . . 565

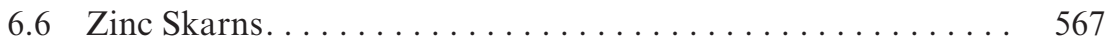

6.7 Molybdenum Skarns . . . . . . . . . . . . . . . . . . . . 568

6.8 Iron Skarns. . . . . . . . . . . . . . . . . . . . . . . . . . . . 569

6.9 Iron, $\mathrm{Au}, \mathrm{Cu}-\mathrm{Mo}$ Skarns in the Yangzte (Chiangjiang) River Valley, China ......................... 570

6.10 The Geodynamic Setting of Skarn (and Porphyry)

Metallogenesis in China . . . . . . . . . . . . . . . . . . . 573

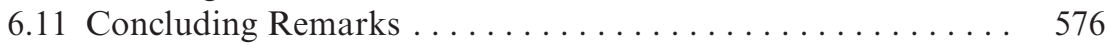

References................................... 577

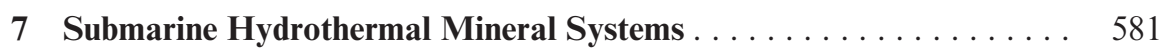

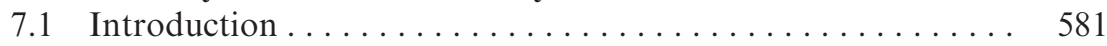

7.2 Physiography of the Ocean Floor ................ 583

$7.2 .1 \quad$ Mid-Ocean Ridges. . . . . . . . . . . . . . . . . . . . 584

7.2.2 Transform Faults and Fracture Zones ........... 586

7.2.3 Seamounts and Volcanic Chains............... 588

7.3 Birth, Life and Death of an Ocean Basin............. 589

7.4 Oceanic Lithosphere and Ophiolites . . . . . . . . . . . . 592

7.4.1 Ophiolites. ....................... 596

7.5 Submarine Hydrothermal Systems: Spreading Centres, Island

Arcs and Seamounts. . . . . . . . . . . . . . . . . . . . 599

7.5.1 Hydrothermal Processes, Nature of Submarine

Hydrothermal Fluids and Anatomy of a Seafloor

Sulphide Deposit.......................... 603

7.5.2 Hydrothermal Systems at Spreading Centres ........ 610

7.5.3 Subduction-Related Submarine Hydrothermal Systems (Island Arcs, Intraoceanic and Intracontinental Back-

Arc Basins) ........................ 632

7.6 Oceanic Crust-Related (Ophiolite) Hydrothermal Mineral Systems in the Geological Record . . . . . . . . . . . . . . . . . . 649

7.6.1 Massive Sulphide Deposits of the Samail Ophiolite, Oman. . . . . . . . . . . . . . . . . . . . . . . . . . . . 649

7.6.2 The $\mathrm{Cu}$ Deposits of Cyprus Island ............. 652

7.6.3 The Besshi-Type Cu Deposits of the Matchless

Amphibolite Belt, Namibia ................. 655

7.7 Volcanic-Associated Massive Sulphide Ore Systems (VMS) . . 662

7.7.1 Kuroko-Type Mineral Systems . . . . . . . . . . . . . . . . . 665

7.7.2 The Kuroko Deposits of Japan.................. 679

7.7.3 Noranda or Abitibi-Type Type Massive Sulphide

Deposits........................... 
7.7.4 The VMS Deposits of Tasmania, Australia . . . . . . . . 687

7.7.5 The Iberian Pyrite Belt Massive Sulphide Deposits . . . 693

7.7.6 The Oldest VMS: Pilbara Craton, Western

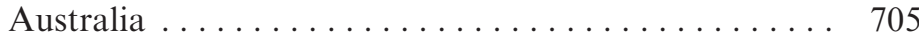

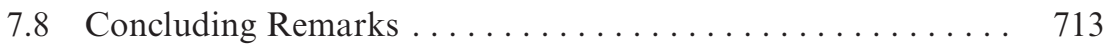

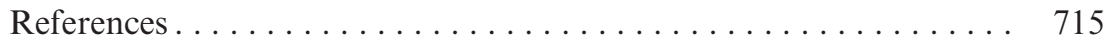

8 Metalliferous Sediments and Sedimentary Rock-Hosted Stratiform and/or Stratabound Hydrothermal Mineral Systems . . . . . . . . . . . . . . . 727

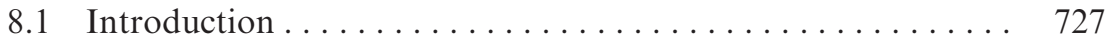

8.2 Basin Formation and Volcano-Sedimentary Successions in Continental Rifts ...................... 731

8.3 Fluid Dynamics in Sedimentary Basins . . . . . . . . . . . . . . . . 736

8.4 The East African Rift System. . . . . . . . . . . . . . . . . . . 741

8.4 .1 Lake Tanganyika. . . . . . . . . . . . . . . . . . . 748

8.4 .2 The Afar Triangle . . . . . . . . . . . . . . . . 750

8.5 Red Sea Brine Pools . . . . . . . . . . . . . . . . . . 751

8.5.1 The Atlantis II Deep . . . . . . . . . . . . . . . 756

8.5.2 Mechanisms for the Formation of the Red Sea Metalliferous Sediments ............... 760

8.6 Stratiform and Stratabound Sedimentary Rock-Hosted

Disseminated Cu Sulphides Ore systems . . . . . . . . . . . 761

8.6.1 The Central African Copperbelt . . . . . . . . . . . . . 766

8.6.2 Stratabound $\mathrm{Cu}-\mathrm{Ag}$ Deposits of the Irumide Belt in Southern Africa . . . . . . . . . . . . . . . . . 773

8.6 .3 Genetic Models ... . . . . . . . . . . . . . . . . 778

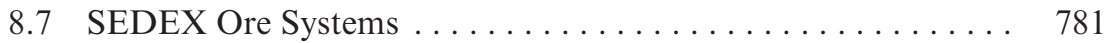

8.7.1 SEDEX Systems in Australia . . . . . . . . . . . . . 786

8.7.2 SEDEX Systems in Southern Africa . . . . . . . . . . . . . 809

8.8 Stratabound Carbonate Rock-Hosted Ore Systems . . . . . . . 815

8.8.1 Mississippi Valley-Type Deposits of the Viburnum Trend

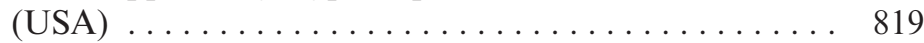

8.8 .2 Alpine-Type Deposits . . . . . . . . . . . . . . 821

8.8 .3 Irish Midlands Deposits . . . . . . . . . . . . . . 823

8.8.4 Models of Ore Genesis for MVT Ore Systems . . . . . . . 825

8.8.5 The Pb-Zn-Cu-Ag-V Deposits of the Otavi Mountain

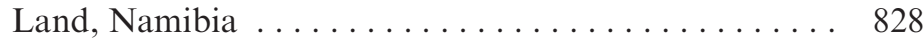

8.8.6 MVT Deposits of the Lennard Shelf, Western Australia . . . . . . . . . . . . . . . . . . . . . 840

8.8.7 MVT Deposits in the North Sea? . . . . . . . . . . . . . . 843

8.9 Iron Formations and Manganese Deposits . . . . . . . . . . . . . 843

8.9.1 Iron Formation Ore Systems and Genetic Models . . . . 850

8.9.2 Granular Iron Formation of the Palaeoproteroroic Earaheedy Basin, Western Australia. . . . . . . . . . . . 857

8.9 .3 Manganese Oxide Ores . . . . . . . . . . . . . . . . . . . 861 
8.10 Metalliferous Sediments on Seafloors . . . . . . . . . . . . 864

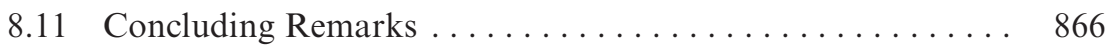

References............................... 867

9 Orogenic, Amagmatic and Hydrothermal Mineral Systems of Uncertain

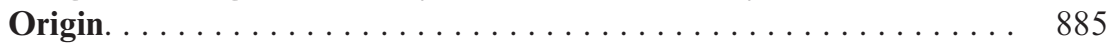

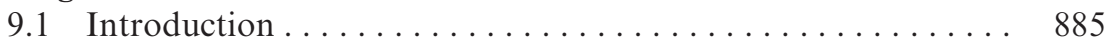

9.2 Orogenic and Metamorphism-Related Lode Systems . . . . . . . 887

9.2.1 Metamorphism and Fluid Generation;

Metamorphogenic Hydrothermal Systems . . . . . . . . . 895

9.2.2 Fluid Paths: Shear Zones, Faults and Thrust

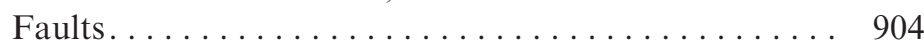

9.2.3 Veins in Metamorphic Rocks ................. 907

9.2.4 Oxygen and Hydrogen Isotope Systematics . . . . . . . . . 909

9.3 Orogenic Lodes. . . . . . . . . . . . . . . . . . . . . . . . . . . . . . 909

9.3.1 Yilgarn Craton, Western Australia .............. 915

9.3.2 Hemlo Au-Mo Deposit, Abitibi-Wawa Greenstone Belt, Superior Province, Canada . . . . . . . . . . . . . . . . 920

9.3.3 Muruntau, Uzbekistan ................... 925

9.3.4 Sukhoi Log Au-PGE Deposit of the Lena Goldfield, Russia; Multi-Stage Origin with a Late Metamorphic Overprint .......................... 929

9.3.5 Orogenic Au Lodes of the South Island, New Zealand . 935

9.3.6 Precious Metal Lode Deposits in the North China Craton 944

9.3.7 Orogenic Lodes and Lamprophyres . . . . . . . . . . . . 963

9.4 Carlin-Type Gold Deposits . . . . . . . . . . . . . . . . . 965

9.4.1 Carlin Deposits of Nevada, Western USA . . . . . . . . . 966

9.4.2 The Carlin Deposit . . . . . . . . . . . . . . . . . . . . . 969

9.4.3 Genetic Models .......................... 971

9.5 Metalliferous Black Shales ...................... 974

9.5.1 Mo-Ni-V-PGE-Au in Black Shales, Southern China:

Seafloor Venting, Seawater Precipitation, or

Impact-Related?. . . . . . . . . . . . . . . . . . 976

9.6 Nonsulphide Mineral Systems . . . . . . . . . . . . . . . . . 981

9.6.1 Classification and Genetic Models . . . . . . . . . . . . 982

9.6.2 Magellan Pb Deposit, Western Australia . . . . . . . . . 985

9.6 .3 Skorpion, Namibia . . . . . . . . . . . . . . . . . . . . 989

9.7 Amagmatic Hydrothermal Systems Related to High Heat

Producing Granites. . . . . . . . . . . . . . . . . . 990

9.7.1 Southwest England and Cornwall High Heat Producing Granites and Associated Hydrothermal Systems . . . . . . 992

9.7.2 Central Australian Heat Flow Province ... . . . . . . . . 995

9.8 An Unusual Amagmatic Mineral System in Inglefield Land, NW

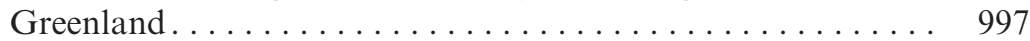

9.8.1 Mineralisation in Northeastern Inglefield Land . . . . . . 1000 
9.8.2 Origin of the Rust Zones and Ore Genesis: A New Mineralisation Style?. . . . . . . . . . . . . . 1002

9.9 Concluding Remarks . . . . . . . . . . . . . . . . . . 1007

References ... . . . . . . . . . . . . . . . . . . . . . . . . . . . . . . . 1009

10 Hydrothermal Systems and the Biosphere . . . . . . . . . . . 1025

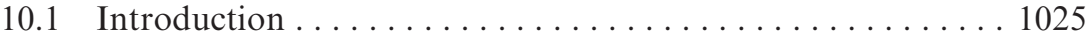

10.2 The Emergence of Life on Earth . . . . . . . . . . . . . . 1026

10.2.1 Panspermia ... . . . . . . . . . . . . . 1030

10.2.2 Synthesis of Prebiotic Molecules, Organic Soups and Warm Little Ponds?. . . . . . . . . . . . . . . . . . 1032

10.2.3 Sulphide Bubbles in Seafloor Hydrothermal Vents. . . 1033

10.2.4 Models Based on Minerals Other than Sulphides . . . 1036

10.2.5 The First Signs of Life on Earth and the Great Oxidation Event .................... 1037

10.2.6 Is Life Being Created Today? . . . . . . . . . . . . . . . . . 1044

10.3 Hydrothermal Systems and the Biosphere; the Role of Bacteria in Ore Genesis. . . . . . . . . . . . . . . . . . . . . . . . . . . . . . . 1046

10.3.1 High-Temperature Ecosystems Associated with

Mineralisation . . . . . . . . . . . . . . . . 1050

10.3.2 Microbes Inside Rocks and in the Deep Subsurface. . 1062

10.3.3 Role of Bacteria in the Weathering Profile . . . . . . . . 1064

10.4 Gas Hydrates, Mud Volcanoes, Seafloor Seeps, Methanogens

and Chemosynthetic Communities. . . . . . . . . . . . 1065

10.4.1 Hydrate Ridge . . . . . . . . . . . . . . . . . . . 1068

10.4.2 Mud Volcanoes and Gas Hydrate Constructs in the

Geological Record. . . . . . . . . . . . . . . . . 1071

10.5 Hydrothermal Ecosystems in the Geological Record . . . . . . 1073

10.5.1 The Rio Tinto Basin, Spain . . . . . . . . . . . . . . . . . 1073

10.5.2 Cretaceous Polymetallic Ore Deposit in Georgia . . . . 1077

10.5.3 Mid-Palaeozoic Hot Spring Deposits and Associated

Ecosystems, Queensland, Australia . . . . . . . . . . 1077

10.5.4 Palaeo- to Mesoarchaean Ecosystems Associated with Hydrothermal Activity in the East Pilbara Terrane . . 1079

10.6 Concluding Remarks . . . . . . . . . . . . . . . . . . . . . . 1087

References ........................... 1088

11 Hydrothermal Processes Associated with Meteorite Impacts . . . . . . 1097

11.1 Introduction . . . . . . . . . . . . . . . . . . . . . 1097

11.2 Asteroid and Cometary Impacts and Hydrothermal

Circulation . . . . . . . . . . . . . . . . . . . . . . . 1098

11.2.1 A Working Model . . . . . . . . . . . . . . . . 1100

11.3 Mineral Deposits and Impact Structures . . . . . . . . . . . . . . . . . . 1102

11.3.1 The Sudbury Hydrothermal System . . . . . . . . . . . 1103

11.3.2 The Lockne Impact Structure . . . . . . . . . . . . . . . 1105 
11.3.3 The Vredefort Meteorite Impact and the Case for Witwatersrand Gold .................. 1106

11.4 Australian Examples of Impact-Related Hydrothermal

Activity . . . . . . . . . . . . . . . . . . . . . . . . 1111

11.4.1 Shoemaker Impact Structure. . . . . . . . . . . . . . . . . . . . . . 1112

11.4.2 Yarrabubba Impact Structure . . . . . . . . . . . . . 1118

11.4.3 Woodleigh Impact Structure . . . . . . . . . . . . . . . . 1121

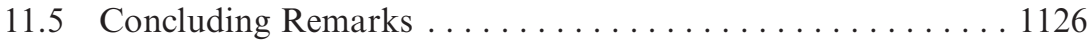

References ............................... 1126

12 Hydrothermal Processes and Systems on Other Planets and Satellites: Clues for the Search of Extraterrestrial Life . . . . . . . . . . . . . . 1131

12.1 Introduction . . . . . . . . . . . . . . . . . 1131

12.2 Extraterrestrial Water. . . . . . . . . . . . . . . . . . . 1131

12.3 Mars ........................... 1133

12.3.1 Volcanism, Rifting and Mantle Plumes. . . . . . . . . 1139

12.3.2 The Findings by the Spirit and Opportunity Rovers ....................... 1145

12.3.3 The Findings of the OMEGA Mission and Their Implications . . . . . . . . . . . . . . . . . . . 1149

12.3.4 Water and Potential Hydrothermal Systems on Mars . . . . . . . . . . . . . . . . . . . . . 1152

12.3.5 Impact Craters . . . . . . . . . . . . . . . . 1162

12.4 Europa, Ganymede, Enceladus and Titan . . . . . . . . . . 1163

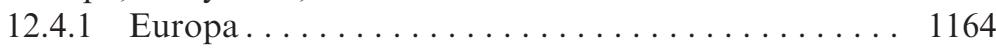

12.4 .2 Ganymede ....................... 1170

12.4 .3 Enceladus............................ 1174

12.4.4 Titan ......................... 1177

12.5 Where to in the Search for Extraterrestrial Life? . . . . . . . . . 1181

12.5.1 Where There is Water There is Life? . . . . . . . . . . . 1182

12.5.2 The Search for Extraterrestrial Life. . . . . . . . . . . 1183

12.6 Concluding Remarks . . . . . . . . . . . . . . . . . 1201

References ............................. 1203

13 Uranium Hydrothermal Mineral Systems . . . . . . . . . . . . . . . . 1213

13.1 Introduction . . . . . . . . . . . . . . . 1213

13.2 Uranium Geochemistry and Decay Schemes . . . . . . . . . . . 1214

13.2.1 Organic Geochemistry of Uranium . . . . . . . . . . . . 1216

13.2.2 Decay Schemes ... . . . . . . . . . . . . . 1218

13.3 Uranium Hydrothermal Mineral Systems . . . . . . . . . . . . 1220

13.3.1 Plutonic Associations . . . . . . . . . . . . . . . . . . 1224

13.3.2 Unconformity-Related U Deposits . . . . . . . . . . . 1229

13.3.3 Sandstone-Hosted/Roll Front U Deposits . . . . . . . 1235

13.3.4 Time-Bound Character of U Mineral Systems . . . . . . . . . . . . . . . . . . . . . . . . 1237 
13.4 Concluding Remarks . . . . . . . . . . . . . . . . . . . . 1238

References .............................. 1239

Index . . . . . . . . . . . . . . . . . . . . . . . . . . . . . . . . . 1243 


\section{Introduction}

In this book I discuss and describe examples of hydrothermal mineral systems and of individual deposits, whose choice and geographic provinciality is based partly on personal experience and/or knowledge of the deposit(s) in question, partly on features of some specific ore systems and aspects thereof that I consider important for illustrating models of ore genesis, which may be useful as a knowledge base. I have drawn heavily from published literature and from my own publications. The reader will also note that some examples of ore systems are described at greater length than others. The reason for this inbalance is that some mineral systems and/ or deposits are especially suitable in providing insights that have more general applications. One reviewer noted that in some chapters I dwell at some length in the discussion of some aspects of Chinese geology and mineralisation. I make no apologies for this occasional predilection. For the past fourteen years I have been increasingly involved in the study of the tectonics and mineral deposits of China, together with Chinese colleagues from a number of research institutions (see Acknowledgments).

In this Introduction and before outlining the nature and contents of this book, I think it appropriate to discuss some issues of definitions and classification of ore deposits.

\section{Definitions and Classifications of Ore Deposits}

The terms mineral deposit, ore deposit, mineral occurrence, prospect, mine, reserves and resources are familiar, but more rigorous definitions are often needed for scientific accuracy and/or legal requirements.

Cox and Singer (1986) defined mineral deposits as occurrences of a valuable commodity (e.g. copper) or mineral (e.g. barite) that are of sufficient size and concentration (grade) that they might, under favourable circumstances, be considered to have potential for economic exploitation. An ore deposit is a mineral deposit that has been tested and discovered to be of sufficient size, grade and accessibility to allow it to be extracted at a profit. Guilbert and Park (1986) considered ores as rocks or minerals that can be mined, processed and 
delivered to the market place or to technology at a profit. Mineral deposit carries no necessary profitability implications and usually denotes subeconomic or incompletely evaluated occurrences of ore minerals. Mineral occurrences or ore-mineral occurrences are uneconomic, but still anomalous concentrations of minerals that may form ores elsewhere.

Reserves include orebodies in production, or known by drilling or other specific measurements, to exist. Reserves are subdivided into measured, indicated and inferred, following the regulations set out by the JORC Code (2004). Resources include reserves and all other potentially viable mineral deposits that are either unknown or uneconomic at present, but can still be reasonably expected to exist.

Definitions set out in Cooper et al. (1998) are applied by the Geological Survey of Western Australia and these include prospect as any working or exploration activity that has found subeconomic mineral occurrences, and from which there is no recorded production. Operating mines are workings that are operating, including on a care-and-maintenance basis, or that are in development leading to production.

In every day practice, and in the majority of recent publications, the general term ore deposit is used a broader sense to include both economic and non-economic mineral deposits. Mineral system or ore system are terms used interchangeably in this book. The concept of a mineral (ore) system is analogous to that of a petroleum system, but owing to the nature of ore deposits and host rocks, a mineral system is far more diverse and complex. The formation of an ore deposit requires a source of metals, a mode of transport (usually a hydrothermal fluid, but also can be a magma) and a site of deposition or accumulation, where commodities become concentrated to enable economically viable extraction during a given period. A mineral system includes all geological and geodynamic factors, at all scales, that control the inception, evolution and preservation of ore deposits, sensu lato. Thus, the study of mineral systems necessarily must integrate;

(1) local studies on recognised deposits, including such factors as;

- local geology, rock types and structural controls

- location of potential accumulation sites

- the physico-chemical processes leading to deposition;

with

(2) regional scale studies including

- geodynamic (tectonic) controls on timing and location of ore deposits (space-time distribution)

- terrane-scale physico-chemical processes that determine how ore deposits are formed;

- the evolution of magmas and other energy sources and fluids at the scale of mineralising systems that influence the location of individual deposits

- regional context 


\section{Classifications and Models}

The systematic classification of ore deposits is inherently fraught with many difficulties. These stem from a large number of variables (lithological, structural, chemical and tectonic), all of which interact to make the observed data difficult to interpret. Frimmel (2007), referring to Au deposits, stated that "a given deposit may be classified according to host rock (e.g. sediment-hosted), or according to a preferred genetic model (e.g. orogenic), the classification may emphasize a specific metal association (e.g. iron oxide copper gold), or it may be based on a comparison with a large prototype (e.g. Carlin type)".

The recently recognised role of meteorite megaimpacts as an important geological process adds to an already complex scenario. Any classification scheme has to take into account that ore deposits are formed by one or more of three fundamental processes, namely: magmatic, hydrothermal, mechanical and residual. Each can be further subdivided as follows:

\section{- MAGMATIC}

- Layered intrusions

- Alaskan zoned intrusions

- Mafic lavas

- Sill complexes

- Dykes

- Pegmatites

\section{- MAGMATIC-HYDROTHERMAL}

- Porphyry

- Epithermal

- Skarns

- Intrusion-related

- VMS (Volcanogenic massive sulphides), Kuroko and Besshi types

- Spreading centres sea-floor smokers; Cyprus type

- Alkaline complexes, greisens, pegmatites

- Iron Oxide Copper Gold Uranium and REE (IOCG); Olympic Dam style

\section{- SEDIMENTARY-HYDROTHERMAL}

- Sedimentary exhalative (SEDEX)

- Copperbelt and Kupperschiefer types

- Metalliferous sediments; Red Sea brines

- Mississippi valley type (MVT)

- Iron formations (banded IF, granular IF) and Mn oxides

\section{- AMAGMATIC OR UNCERTAIN ORIGIN}

- Orogenic lodes

- Black shales 
- Carlin type

- Associated with high-heat producing granites

- Meteorite impact structures

\section{- MECHANICAL/RESIDUAL/WEATHERING}

- Placers

- Laterites

If geological processes are used to classify ore deposits, they necessarily rely heavily on genetic factors; however, ore genesis can be extremely complex because it usually involves a number of interactive processes. Genetic classifications lend themselves to mis-interpretations. In fact, variations within the same class of ore deposits can be extreme. For instance, the class of $\mathrm{Cu}-\mathrm{Au}-\mathrm{U}-\mathrm{REE}-\mathrm{Fe}$ (IOCG) deposits includes Olympic Dam (South Australia), the Fe deposits of the Kiruna district (Sweden), Fe-REE deposits of Box Bixby and Pea Ridge (Missouri, USA) and possibly the REE-rich Bayan Obo (Mongolia), the Palabora carbonatitehosted $\mathrm{Cu}$ and the Vergenoug Fe-F deposit (South Africa). When examined in detail all of these deposits are remarkably different. Nevertheless, they all have a common theme: anorogenic mafic to alkaline magmatism in rift settings, with many, but not all, of Proterozoic age.

The alternative is to use a non-genetic classification scheme. This can be done by using host rocks and/or geological environments. However, here too there are problems. For example, $\mathrm{Ni}$ and $\mathrm{Cu}$ deposits hosted in layered mafic-ultramafic rocks in the interior of cratons, comprise such a great variety of types and styles, ranging from primary magmatic to hydrothermal. Another possibility is to consider ore deposits on a combination of descriptive features, such as host rocks and dominant economic metal(s), and genetic features, such as mechanism of fluid movement, temperature of formation, alteration and extent, if any, of magmatic involvement. Some students of ore deposits adopt a descriptive classification based upon the dominant economic metals and then modify individual categories based upon compositional, tectonic, or genetic variations. An example is the classification of porphyry deposits into porphyry copper-gold, porphyry copper-molybdenum, and porphyry tin types.

In reality, none of the above schemes (genetic, non-genetic or mixed geneticnon-genetic) are adequate because they are open to all sorts of debates.

Holistic studies of ore deposits and their classification can be divided into two groups: studies done before plate-tectonics was recognised as a global geological process, and those done afterwards. In the former are the works of Lindgren (1933), Bateman (1967), Stanton (1972), Smirnov (1976) and Jensen and Bateman (1979). To the second group belong Mitchell and Garson (1981), Hutchison (1983), Sawkins (1990), and Guilbert and Park (1986).

Lindgren's (1933) classification of ore deposits remains a landmark achievement. For example, his ideas of epithermal, hypothermal and telethermal are still valid concepts today. Stanton (1972) although focussing on ore petrology, 
which is the title of his book, did provide a useful classification by considering ore deposits in terms of lithological associations, as detailed below:

- Ores of mafic-ultramafic association

- Ores of felsic association

- Iron and manganese concentrations of sedimentary affiliation

- Stratiform sulphides of marine and volcanic association

- Stratabound ores of sedimentary affiliation

- Ores of vein association

- Ores of metamorphic affiliation

Guilbert and Park (1986) adopted a similar approach, by considering ore deposits related to

- Mafic igneous rocks

- Oceanic crust

- Intermediate to felsic intrusions

- Subaerial volcanism

- Submarine volcanism

- Submarine volcanism and sedimentation

- Chemical sedimentation

- Clastic sedimentation

- Weathering

- Regional metamorphism

- Solution-remobilisation

- Doubtful igneous connection

Cox and Singer (1986) preferred to classify ore deposit models by geologicaltectonic environment, thereby devising a tree-like diagram such as those used in life-sciences. In this way, they consider a first division into: igneous, sedimentary, regional metamorphic and surficial. Mitchell and Garson (1981) were amongst the first to enthusiastically espouse the idea that plate tectonics offered a double solution in the difficult task of systematising ore deposits. The idea, with which we are all now familiar, is that plate tectonic processes are responsible for generating ore deposits, therefore ore deposits are effectively an expression of the tectonic setting in which they are formed, but not necessarily the tectonic setting in which they occur. Conversely, a specific type of ore deposit can (and does in many cases) help in unravelling the tectonic setting of a geological terrane. Examples are ophiolite-hosted metal deposits. Some are formed in oceanic crust at a mid-ocean ridge and later tectonically transported onto a continental margin, but the same ophiolite rocks may also host hydrothermal mineralization resulting from deformation and metasomatism during a collision event.

The relationship of ore deposits to plate tectonics led to the formulation of ore deposit models. An ore deposit model describes the essential features (geological, host rocks, wall rock alteration, geochemical/metal associations, spatial distribution, grade, size, ore mineralogy, regional metallogenic 
framework, tectonic setting) of a group or class of deposits. Ore deposit models effectively are sets of data that best describe a deposit or family of deposits, which share similar features and which contain common geological attributes and are formed in similar tectonic environments. A model can be empirical based entirely on facts, such as field observations, geochemical and geophysical data, or theoretical based on conceptual ideas generally borne out of experience and knowledge of, and extrapolation from known mineral districts. Ore deposit models ranges from simplistic (very limited database) to complex (large database); in the same way as few data points define a smooth curve, whereas many points usually define a more complex curve. But, as is the case for a curve derived from many data points, this can be smoothed to obtain a fairly accurate overall picture. This is the one of the keys to understanding ore deposits and their genesis: filter out the noise and home in to a general model that fits within a regional framework and that adequately explains the observations. Another important factor is that an ore deposit can be modified, perhaps more than once, by subsequent geological processes (e.g. collision tectonics, meteorite impacts). The literature on ore deposit models is abundant; some of the more popular works include Roberts and Sheahan (1988), Kirkham et al. (1993) and Du Bray (1995).

Overall the new plate tectonics paradigm fostered the modelling of ore systems, which turned out to be very useful in mineral exploration because of their predictive capacity, although the difficulty of obtaining a classification of ore deposits that completely satisfies both genetic and non-genetic conditions remains. Nevertheless, building a mineral system genetic model provides insights into the geodynamic environment of ore formation and, importantly, allows a degree of predictability that can assist in exploration targeting. A thematic issue of the Australian Journal of Earth Sciences is devoted to conceptual exploration targeting (Groves 2008).

Several other books deal with various aspects of ore deposits. These include: Lindgren (1933), Bateman (1967), Park and MacDiarmid (1970), Smirnov (1976), Mitchell and Garson (1981), Hutchison (1983), Guilbert and Park (1985), Sawkins (1990), Pirajno (1992), Evans (1993), Barnes (1997), Pirajno (2000), Misra (2000), Solomon and Groves (2000) and a recent and very comprehensive treatise by Laznicka (2006). The 100th Anniversary Volume of Economic Geology (Hedenquist et al. 2005) provides excellent and in-depth reviews of both magmatic and hydrothermal mineral systems which include: (1) Magmatic ore deposits (2) porphyry deposits, (3) skarns, (4) granite-related ore deposits, (5) precious metal deposits in metamorphic terranes, (6) Carlinstyle deposits, (7) epithermal precious and base metals, (8) sediment-hosted $\mathrm{Pb}-\mathrm{Zn}$, (9) sediment-hosted stratiform deposits, (10) iron-formations, and (11) the hydrothermal model for the Witwatersrand Au-U deposits. In addition, regional metallogeny and earth environments and processes are discussed in some detail. More recently, the Geological Association of Canada published an extremely well-illustrated book (Goodfellow 2007), which although focussing on the mineral deposits of Canada, does provide excellent reviews of ore systems that are applicable world wide. 


\section{This Book}

This book is about Hydrothermal Processes and Mineral Systems and where appropriate links with life. The book consists of 13 chapters, which can be considered on a "stand-alone" basis. In Chapter 1, I discuss the different sources of water that participate in hydrothermal activity and circulation systems. Hydrothermal fluids can be juvenile-magmatic or derived from seawater, metamorphic, meteoric, connate waters or a mix of two or more of these. I briefly look into solubility, boiling and redox processes. A brief overview is presented on hot springs because they, whether subaqueous or subaerial, are the surface expression of hydrothermal systems. Next I discuss fluid inclusions and isotopic tracers, which provide the means of investigating the nature and composition of the fluids that are involved in ore making processes. Water is a powerful solvent, but the transport of metals in solution is aided and promoted by complex ions ligands. This aspect, together with the precipitation of metal compounds, is also examined in Chapter 1.

The interaction of hydrothermal fluids with wallrocks and/or the hydrosphere and changes in their composition through time and space, contribute to the formation of a wide range of mineral deposit types and associated wallrock alteration. Chapter 2 looks at hydrothermal alteration processes of selected mineral systems, such as anorogenic ring complexes, porphyry, epithermal and skarns and presents examples of types of alteration, such as tourmalinisation, serpentinisation and talc-carbonate. Briefly, I also discuss the effects of metamorphism on hydrothermally altered rocks and the geochemical and isotopic signatures of alteration. A very brief panoramic is provided on the use of spectral remote sensing for the detection of hydrothermal alteration.

As metioned above, an ore system is the product of a set of geodynamic events and as such it bears the signature of these events. This is not easily unravelled, but the constantly improving geochronological techniques are providing the means for distinguishing these tectonic signals. Conversely, knowledge of a tectonic setting can and does afford important clues for understanding a mineral system and also for providing vectors to finding new deposits. In Chapter 3 tectonic settings and associated hydrothermal processes are examined. Hydrothermal processes on Earth have played an important role in the evolution of our planet. These processes link the lithosphere, hydrosphere and biosphere in continuously evolving dynamic systems. Terrestrial hydrothermal processes have been active since water condensed to form the hydrosphere, most probably from about $4.4 \mathrm{Ga}$. The circulation of hot aqueous solutions (hydrothermal systems) at and below the Earth's surface is driven by internal heat. Hydrothermal systems form beneath the oceans (e.g. spreading centres, oceanic plateaux), in lakes, intracontinental rifts, continental margins and magmatic arcs. Tectonic settings have evolved with geological time from mantle plume tectonic-dominated regimes in the Archaean, to a more "buoyant" style tectonics in the Proterozoic, to modern plate tectonics in the Phanerozoic, reflecting the trend of a cooling Earth. 
Therefore, the evolution of hydrothermal processes through geological time is ultimately related to planetary cooling and the mode of heat transfer from the mantle towards the surface (e.g. mantle plume events, associated tectonism, continental volcanism, oceanic magmatism). Thus, some hydrothermal systems and related mineral deposits are strictly time-dependent, for example uranium mineralisation and the huge accumulation of banded iron-formations. The latter reached a peak during the Palaeoproterozoic and were associated with an evolving oxygenated atmosphere and the delivery of large quantities of ferrous $\mathrm{Fe}$ from seafloor hydrothermal venting, possibly associated with mantle superplume events.

The descriptions and discussions on mineral systems commence with intrusion-related deposits in Chapter 4. In this chapter I begin with an overview of granitic magmatism and intrusion-associated hydrothermal and ore-making processes, before embarking on the description of specific intrusion-related systems, which includes classic cases of Sn-W mineralisation, the less known polymetallic Mo-W-Be-Bi deposits in Siberia, Au and polymetallic veins and hydrothermal systems in alkaline complexes. In this same chapter I have included the Fe oxide copper-gold (IOCG) systems. The inclusion of IOCG systems in this chapter may be disputable, but I find that in spite of the diversity of IOCG deposits, a common link seems to be that they are all related to A-type anorogenic intrusions and magmatism.

Porphyry and epithermal systems are presented in Chapter 5. I may be forgiven for the unusual length of this chapter, but this was somewhat unavoidable due to the common and close link between porphyry and epithermal systems. An important point that I have endeavoured to emphasise is that porphyry and epithermal systems are not necessarily related to subduction settings. Indeed, there is abundant evidence for some porphyry deposits to occur in intraplate rift settings and volcanic rifted margins associated with mantle plume tectonics. I have also included in Chapter 5, the oldest porphyry and epithermal systems that are known from the Pilbara Craton in Western Australia, which were also formed in an intraplate setting. Although, also commonly linked with porphyry intrusions, skarns are described in Chapter 6. Skarn systems generally form in carbonate rocks, are typically mineralogically zoned, characterised by mineral assemblages that reflect decreasing temperatures in a dynamic evolving regime away from the contact with the causative intrusions. Skarns provide a wide array of $\mathrm{Sn}, \mathrm{W}, \mathrm{Fe}, \mathrm{Au}$ and base metal ores in tectonic settings ranging from steep to shallow subduction to continental rifting. Skarn systems in eastern China provide a spectrum of mineralisation types and styles that range from veins to disseminated, massive magnetite and sulphides in endoskarn and exoskarns, which in many cases appear transitional to intrusion-related, porphyry and even IOCG systems. These mineral system are controlled by major tectonic boundaries and linked to the activity of asthenopsheric upwellings.

In Chapter 7, I discuss hydrothermal systems in the submarine environments. Truly another fascinating field that has captivated the life science and 
geoscientific communities with the discovery of unsuspected ecosystems that not only thrive in the absence of oxygen and hot temperatures, but also actively participate in precipitating metalliferous compounds. These submarine hydrothermal systems, in my opinion, give us a glimpse on what the early Earth may have been like and on the environments where life may have been generated. Chapter 7 also looks into the physiography of the ocean floor and provides an overview of what hydrothermal systems are like at spreading centres, island arcs and seamounts, giving us invaluable insights on ancient mineral systems that may have originated on the seafloor. Kuroko and Abitibi types massive sulphides deposits are the classic representative of submarine hydrothermal systems in the geological record and again we have examples of the most ancient ones in the Pilbara Craton, where evidence of early life is undeniably present (Chapter 10). Other ancient deposits are more difficult to pigeon-hole and may represent either a unique case or a new system type. In this category I include the Iberian Pyrite Belt, arguably the world's largest metal accumulation, and the unusual Abra deposit in Western Australia.

There is a transition from oceanic seafloor hydrothermal systems, the metalliferous sediments that accumulate well away from hydrothermal vents and hydrothermal systems that actively form in incipient oceanic settings, such as the Red Sea. These are discussed in Chapter 8, in which volcano-sedimentary basins in intracontinental rift settings are the main topic with examples from the great East African Rift System. The East African rifts and the Red Sea together may well present a modern analogue of the variability of rift settings in which giant and world-class sedimentary exhalative (SEDEX) deposits were formed. In this chapter I have included the disseminated $\mathrm{Cu}$-Co sulphides of the Central African Copperbelt and the world-class SEDEX deposits of Australia and South Africa. Mississippi valley-type (MVT) are included in Chapter 8 as part of the stratabound mineral systems, although these may also have been incorporated in Chapter 9. Iron (and $\mathrm{Mn}$ ) formations (banded and granular) not only constitute giant accumulation of $\mathrm{Fe}$ (and $\mathrm{Mn}$ ) but, in the 21st century, are in high demand by the emerging economies resulting in unprecedented prosperity in the supplying countries. Iron formations are time-dependent and effectively confined to passive margins that resulted from supercontinent breakup in the Palaeo-Mesoproterozoic. The deposition of Fe oxides occurred because of changes in oxygen levels in the biosphere-hydrosphere-atmosphere system.

Chapter 9 deals with amagmatic and hydrothermal systems of uncertain origin, amagmatism intended as lack of, unproven or doubtful involvement of magmas. In reality, amagmatism is not entirely proven for the class of orogenic lodes, which continue to defy us on whether there was or not direct or even indirect involvement of magmas. If and where there is such a link then the relevant orogenic lodes can be considered as intrusion-related systems. It is, however, well established that compression in collision orogen and metamorphic devolitilsation processes were implicated in the making of these ore systems. Carlin-type or better Carlin-style deposits too present a challenge in 
that a clear link with magmatic activity remains elusive and fall into a category best considered of uncertain origin. Similarly for black shales, also discussed in this chapter and whose metal endownment's origin is not entirely clear. The example given in this book is that of southern China, where highly mineralised black shales exhibit unusual textures and metal association (Mo-Ni-V-PGE-Au). Given the age and nature of these deposits, I cannot help but wonder if there is a link with a large meteorite impact, with a possible candidate being the Acraman structure in South Australia. Nonsulphide mineral systems, the result of palaeoweathering processes that have operated on MVT deposits, are dealt with in this chapter. Also in Chapter 9, I discuss hydrothermal systems powered by high heat producing granites (HHP) and conclude with an unusual amagmatic mineral system from northwest Greenland.

On Earth, sites of hydrothermal activity support, both at surface and in the subsurface, varied ecosystems based on a range of chemotrophic micro-organisms. An intriguing question is whether primitive life is still being created in present-day hydrothermal systems, or did it occur only in the ancient geological past? These are some of the issues discussed in Chapter 10. Also in this chapter the role of bacterial communities in ore genesis are examined with recent and ancient examples being discussed. On the way, I thought it appropriate to make a brief mention of gas hydrates and associated seafloor seeps and mud volcanoes.

Chapter 11 looks into the role of meteorite impacts as a source of thermal energy for hydrothermal circulation. Accounts of hydrothermal systems associated with meteorite impacts are mostly confined to a somewhat restricted group of geoscientists or "impactologists", who tend to publish in specialist journals. The fact is that large and small meteorite impacts do have a major role in setting up hydrothermal citculation, but because of the poor preservation record of many of the large impact structures, it is difficult to provide tangible proof of impact involvement for some ore systems (for instance the abovementioned polymetallic black shales in southern China). The Witwatersrand conglomerates, the largest accumulation of $\mathrm{Au}$ in the world, may have been preserved and/or locally re-distributed by hydrothermal fluids, generated by the large and oldest known impact structure ( $2.02 \mathrm{Ga}$; Vredefort). An intriguing hypothesis, difficult to prove, due to the succession of thermal events that affected the Witwatersrand basin.

It is also possible that hydrothermal processes operate or operated on other planets, such as Mars, where liquid water is, or was present and even in some of the satellites of the Jovian planets. These are examined in Chapter 12. The recent and on-going space missions continue to supply astonishing large amounts of data that will take years to completely absorb and assess. NASA reports are regularly posted on web sites, often reporting new finds. Maintaining a connection with these web sites is akeen to each time opening a window on a new view. Our vision of the "cradle of life" has surely changed, life, as we know it, needs water and planet Earth must have been a very different place 3.5-4 billion years ago when life first appeared. The Earth must have had far greater lengths of deep sea ridges, volcanoes and submarine hydrothermal vents releasing large quantities 
of nutrients, than in later ages. In spite of frequent meteoritic bombardment, there must have been several well protected "hydrothermal ponds" where microbial life thrived. The challenge now is to find these "hydrothermal ponds" on other planets, with Mars being the best candidate, but certainly not excluding the very far away Galilean satellites, where deep oceans may exist beneath a crust of ice. Chapter 12 examines Europa, Ganymede, Enceladus and Titan as these possible candidates.

Chapter 13 is the last in this book and it deals exclusively with uranium mineral systems. Nuclear energy is a politically sensitive subject in many countries, but one which sooner or later needs to be accepted. Canada and Australia have large uranium resources, mostly contained in unconformity-related ore systems. In Australia, substantial resources are also contained in IOCG systems, such as Olympic Dam, discussed in Chapter 4. I have included in this chapter the alaskite-hosted $U$ deposits, with the best example being provided by Rössing in Namibia.

Finally, I take full responsibility for the contents of this book. If I have misrepresented or misquoted some of the concepts or ideas obtained from the literature, this was unintentional and in no way reflects a disregard for the original author(s)' work.

Spelling is English Australia (Moore 2000), except in references where original spelling is maintained. Unless otherwise explained, the abbreviations and symbols used in this book (e.g. Mt for million tonnes, t for tonnes, element symbols, such as $\mathrm{Cu}$ for copper, $\mathrm{Ag}$ for silver and so forth, $\sim$ for circa, wt $\%$ for weight percent, ppm for part per million, $\mathrm{g} / \mathrm{t}$ grams per tonne, kbar for kilobar etc) should be familiar to all Earth scientists.

\section{References}

Barnes HL (ed) (1997) Geochemistry of hydrothermal ore deposits, 3rd edn, John Wiley \& Sons, New York, 972 pp

Bateman AM (1967) Economic mineral deposits. John Wiley \& Sons, New York, 916 pp

Cooper RW, Langford RL, Pirajno F (1998) Mineral occurrences and exploration potential of the Bangemall Basin. Geol Surv West Aust, Report 64

Cox D, Singer DA (eds) (1986) Mineral deposits models: US Geol Surv Bull 1693

Du Bray EA (ed) (1995) Preliminary compilation of descriptive geoenvironmental mineral deposits models: U. S. Department of the Interior, U S Geol Surv Open File Rep 95-831

Evans AM (1993) Ore geology and industrial minerals - An introduction. Blackwell Scientific Publ, Oxford

Frimmel HE (2007) Earth's continental crust gold endowment. Earth Planet Sci Lett, doi:10.1016.j.epsl.2007.11.022

Goodfellow WD (ed) (2007) Mineral deposits of Canada - A synthesis of major deposit types, district metallogeny, the evolutionof geologicalprovinces and exploration methods. Geol Ass Can Sp Publ 5

Groves DI (ed) (2008) Coceptual mineral exploration. Aust J Earth Sci 55(1)

Guilbert JM, Park CF (1986) The geology of ore deposits. Freeman, San Francisco

Hedenquist JW, Thompson JFH, Goldfarb RJ, Richards JP (eds) (2005) Economic Geology One Hundreth Anniversary Volume. Soc Econ Geol, Littleton, Colorado 
Hutchison CS (1983) Economic deposits and their tectonic settings. The MacMillan Press Ltd, London, $355 \mathrm{pp}$

Jensen M L, Bateman AM (1979) Economic mineral deposits: John Wiley \& Sons, New York

JORC Code (2004) Australasia code for reporting of exploration results, mineral resources and ore reserves. Austral Inst Min Metall, Aust Inst Geosci, Min Council Aust

Kirkham RV, Sinclair WD, Thorpe RI, Duke JM (eds) (1993) Mineral deposit modeling: Geological Association of Canada Special Paper 40

Laznicka P (2006) Giant metallic deposits; future sources of industrial metals. Springer, New York

Lindgren W (1933) Mineral deposits. McGraw-Hill Book Co, New York

Misra KC (2000) Understanding mineral deposits. Kluwer Academic Publishers, Dordrecht

Mitchell AHG, Garson MS (1981) Mineral deposits and global tectonic settings. Academic Press, London

Moore B (ed) (2000) The Australian Oxford dictionary. Oxford Univ Press, Oxford

Park CF, MacDiarmid RA (1970) Ore deposits, 2nd edn, W. H. Freeman \& Co, San Francisco

Pirajno F (1992) Hydrothermal mineral deposits - principles and fundamental concepts for the exploration geologist. Springer-Verlag, Berlin, 709 pp

Pirajno F (2000) Ore deposits and mantle plumes. Kluwer Academic Publishers, Dordrecht

Roberts RG, Sheahan A (1988) Ore deposit models: Geoscience Canada Reprint Series 3

Sawkins FJ (1990) Metal deposits in relation to plate tectonics, 2nd edn, Springer-Verlag, Berlin

Solomon M, Groves DI (2000) The geology and origin of Australia's mineral deposits. Centre for Ore Deposit Research and Centre for Global Metallogeny, Univ West Austr Publ 32

Smirnov VI (1976) Geology of mineral deposits. MIR Publishers, Moscow

Stanton RL 1972, Ore petrology: McGraw-Hill Book Co 